\title{
LAS AYUDAS COMPENSATORIAS A LAS VÍCTIMAS DE TERRORISMO: ANÁLISIS DE LA LEY 29/2011 Y SU REGLAMENTO DE DESARROLLO
}

\author{
Natalia Pérez Rivas
}

doi: 10.18543/ed-64(2)-2016pp157-188

\begin{abstract}
SuMARIO: 1. LA COMPENSACIÓN ESTATAL A LAS VÍCTIMAS DE TERRORISMO EN LA LEGISLACIÓN ESPAÑOLA: REVISIÓN NORMATIVA. 2. NUEVO RÉGIMEN GENERAL DE AYUDAS E INDEMNIZACIONES A LAS VÍCTIMAS DEL TERRORISMO: LA LEY 29/2011. 2.1. Previsiones generales. 2.1.1. Naturaleza jurídica. 2.1.2. Ámbito subjetivo. 2.1.3. Ámbito espacial. 2.1.4. Ámbito temporal. 2.1.5. Régimen de compatibilidad. 2.1.6. Exenciones. 2.1.7. Actualización de la cuantía resarcitoria. 2.2. Regímenes de ayudas a las víctimas de terrorismo. 2.2.1. Régimen ordinario de ayudas. 2.2.2. Abono de la responsabilidad civil fijada en sentencia. 2.2.3. Régimen extraordinario de ayudas. 3. CONCLUSIONES. 4. BIBLIOGRAFÍA
\end{abstract}

\section{LA COMPENSACIÓN ESTATAL A LAS VÍCTIMAS DE TERRORISMO EN LA LEGISLACIÓN ESPAÑOLA: REVISIÓN NORMATIVA}

El primer antecedente legislativo del establecimiento de obligaciones a cargo del Estado para la atención a las víctimas del terrorismo es el Decreto ley $10 / 1975$, de 26 de agosto, sobre prevención del terrorismo ${ }^{1}$,

${ }^{1}$ BOE núm. 205, de 27 de agosto de 1975. José Leandro MartíneZ-CARDós Ruíz, El resarcimiento estatal de daños causados por bandas y grupos armados (tesis doctoral, Universidad Complutense de Madrid, 1996), 35-44. 
disponiéndose en su art. 21 que «el Estado indemnizará especialmente los daños y perjuicios que se causaren a las personas con ocasión de su actividad o colaboración para la prevención o represión» de actos terroristas ${ }^{2}$.

Este Decreto fue derogado posteriormente por el Real Decreto-ley 3/1979, de 26 de enero de 1979, de Protección de la Seguridad Ciudadana ${ }^{3}$, en cuyo art. 7, utilizando una fórmula similar a la del anterior decreto, amplió el ámbito de aplicación de la indemnización estatal a los daños y perjuicios que se causaren a las personas como consecuencia de los actos delictivos cometidos por personas integradas en grupos o bandas organizadas y armadas y sus conexos ${ }^{4}$. Será el Real Decreto 484/1982, de 5 de marzo de $1982^{5}$, el que se ocupe de regular la compensación estatal por los daños personales producidos por dichas acciones ${ }^{6}$.

A la aprobación de esta última norma han seguido numerosas reformas y nuevas disposiciones dirigidas a mejorar el ámbito de cobertura, ampliar el círculo de posibles beneficiarios o incrementar la cuantía de la ayuda, articulando un sistema compensatorio mucho más generoso que el previsto para las víctimas «comunes» ${ }^{7}$. Esta situación se justifica en consideración a la alarma que despiertan este tipo de delitos, dado su carácter indiscriminado e

${ }^{2}$ Esta temprana y primigenia regulación del sistema reparador de las víctimas de terrorismo es una clara muestra del estatuto jurídico privilegiado del que aquéllas han gozado en España. Y es que, como afirma Josep María TAmarit Sumalla, «Paradojas y patologías en la construcción social, política y jurídica de la victimidad», Indret: Revista para el Análisis del Derecho (2013): 22, «se empezaron a adoptar las primeras medidas de indemnización y apoyo a las víctimas [de terrorismo], cuando todavía no se había producido una sensibilización a favor de las víctimas del delito en general».

3 BOE núm. 28, de 1 de febrero de 1979.

${ }^{4}$ El art. 7 del Real Decreto-Ley 3/1979 establecía que «serán especialmente indemnizables por el Estado los daños y perjuicios que se causaren a las personas con ocasión de las actividades delictivas a que se refiere el núm. uno del art. 3 - «Todos los cometidos por persona o personas integradas en grupos o bandas organizados y armados y sus conexos»- de este Real Decreto-Ley. El Gobierno determinará el alcance y condiciones de dicha indemnización».

${ }_{5}$ Real Decreto 484/1982, de 5 de marzo, por el que se desarrolla el Real Decreto-ley 3/1979, de 26 de enero (BOE núm. 60, de 11 de marzo de 1982).

${ }^{6}$ Martínez-Cardós Ruíz, El resarcimiento..., 35-44.

7 El criterio de otorgar un tratamiento diferente a las víctimas, en función de que lo sean o n. $^{\circ}$ de actos terroristas, se observa también en las legislaciones de otros países de nuestro entorno, como Italia y Francia. Jo GOODEY, «Compensating victims of violent crime in the European Union with a special focus on victims of terrorism». Comunicación presentada en la Mesa Redonda sobre compensación a las víctimas, el 10 de junio de 2003. Washington, DC: Centro Nacional para las Víctimas del Crimen. Disponible en: http://www.ncvc.org/ncve/AGP.Net/Components/documentViewer/Download. aspxnz?DocumentID=32594. Acceso el 30 de septiembre de 2016. 
imprevisible ${ }^{8}$, así como por la mayor sensibilidad social que estos hechos generan y por su especial objeto de ataque (el orden político democráticamente establecido $)^{9}$.

La primera de esta serie de normas fue la Ley Orgánica 9/1984, de 26 de diciembre, contra la actuación de bandas armadas y elementos terroristas ${ }^{10}$, cuyo capítulo IV versaba sobre la indemnización por daños personales causados como consecuencia o con ocasión de la comisión de actividades derivadas de hechos terroristas. Esta ley fue desarrollada por el Real Decreto $336 / 1986$, de 24 de enero ${ }^{11}$, que reguló exhaustivamente las indemnizaciones a las víctimas de bandas armadas y elementos terroristas, disciplinando aspectos como el concepto y alcance de la indemnización, la determinación de los titulares del derecho al resarcimiento, los criterios para el cálculo de la cuantía de la indemnización y el plazo de prescripción de la acción ${ }^{12}$.

Tras su derogación por la Ley Orgánica 3/1988, de 25 de mayo, de reforma del Código penal ${ }^{13}$, se procedió a dar cumplimiento al mandato establecido en el art. 64.1 de la Ley 33/1987, de 23 de diciembre, de Presupuestos Generales del Estado para $1988^{14}$, que habilitó al Gobierno para determinar reglamentariamente el alcance y condiciones de la compensación estatal por los daños personales causados como consecuencia o con ocasión de actividades delictivas cometidas por bandas armadas o elementos terroristas. Ese mandato legal se hizo efectivo en el Real Decreto 1311/1988, de 28 de

${ }^{8}$ Ernesto GARZÓN VALDÉS, «El terrorismo político no institucional: propuesta de definición», Claves de Razón Práctica, n. ${ }^{\circ} 118$ (2001): 11, define el terrorismo político no institucional como «un método expansivo de la amenaza o del uso intencional e imprevisible de la violencia por parte de individuos o grupos no gubernamentales, destinado a provocar en una sociedad el temor generalizado, infligiendo daños inevitables a personas inocentes con miras a influir en el comportamiento de terceros, a fin de obtener objetivos políticos fanáticamente percibidos como no negociables».

9 Como explicita Gerardo Landrove DíAz, La moderna victimología (Valencia: Tirant lo Blanch, 1998), 141-142, el fundamento último de la limitación inicial del programa de compensación estatal a las víctimas del terrorismo así como la mayor protección que en la actualidad se les sigue dispensando es político.

${ }^{10}$ BOE núm. 3, de 3 de enero de 1985.

11 Real Decreto 336/1986, de 24 de enero, por el que se regulan las indemnizaciones a las víctimas de bandas armadas y elementos terroristas (BOE núm. 43, de 19 de febrero de 1986).

12 Martínez-Cardós Ruíz, El resarcimiento..., 48-54. LANDRove Díaz, La moder$n a \ldots, 144$ etiquetó la regulación contenida en dicho Real Decreto como el modelo a seguir para la configuración de un sistema de compensación estatal a favor de las víctimas de otro tipo de delitos.

13 BOE núm. 126, de 26 de mayo de 1988.

14 BOE núm. 307, de 24 de diciembre de 1987. 
octubre $^{15}$, que amplía considerablemente el círculo de titulares del derecho a obtener un resarcimiento fijado por el citado Real Decreto 336/1986, incluyendo en él a todas las personas que tengan determinados lazos de parentesco con las víctimas, y se hallen en una situación de dependencia económica real y demostrada de la misma ${ }^{16}$.

El art. 64 de la Ley 33/1987 sufrió diversas modificaciones. La primera de ellas fue operada por la disposición adicional decimosexta de la Ley 4/1990, de 29 de julio, de Presupuestos Generales del Estado para 199017, y tuvo por objeto sustituir el criterio utilizado hasta la fecha para la indemnización de las lesiones no invalidantes (el baremo de indemnizaciones vigente en cada momento en el sistema de Seguridad Social), por una regla de cuantificación uniforme que tiene por base el salario mínimo interprofesional (en adelante SMI). La disposición sanciona, asimismo, la posibilidad de conceder las ayudas con carácter provisional, teniendo en cuenta las circunstancias concurrentes, durante la tramitación de los expedientes. La segunda modificación fue introducida por la disposición adicional decimonovena de la Ley 31/1991, de 30 de diciembre de Presupuestos Generales del Estado para $1992^{18}$, y su sentido fue el de ampliar los daños que dan lugar al resarcimiento a los ocasionados en la vivienda habitual de las personas físicas ${ }^{19}$.

${ }_{15}$ Real Decreto 1311/1988, de 28 de octubre, por el que se regulan los resarcimientos a las víctimas de bandas armadas y elementos terroristas (BOE núm. 265, de 4 de noviembre de 1988).

${ }^{16}$ Martínez-CARdós Ruíz, El resarcimiento..., 54-60; Josep María TAMarit SumALLA, La reparación a la víctima en el derecho penal (Barcelona: Fundación Jaume Callís, 1994), 89-91, se encarga de realizar un análisis de esta norma, valorando las diferentes modificaciones introducidas en el sistema creado por la Ley especial de 1984. El Real Decreto 336/1986 reconocía el derecho a obtener indemnización a los siguientes grupos de sujetos: a) en caso de lesiones a las persona o personas que las hubiesen sufrido; y b) en caso de muerte, al cónyuge no separado legalmente, a los hijos de la víctima cualquiera que fuese su filiación - menores de edad o mayores legalmente incapacitados o notoriamente incapaces de procurar su sustento-, al progenitor de algún hijo del difunto con derecho a resarcimiento, siempre que lo tuviera bajo su custodia; $y$, finalmente, en ausencia de todos los anteriores, a los ascendientes de la víctima en primer grado. A ellos, y en su defectos, se añadieron en virtud del Real Decreto 1311/1988, los hermanos de la víctima -siempre que conviviesen y dependiesen económicamente de ésta y no tuvieran medios suficientes de subsistencia-, y, excepcionalmente, y para los casos de muerte de los progenitores y de algún hijo común de ambos, los hijos supervivientes respecto de sus hermanos, sin necesidad de que concurran las circunstancias de la convivencia y dependencia económica anteriormente aludidas.

17 BOE núm. 156, de 30 de junio de 1990.

18 BOE núm. 313, de 31 de diciembre de 1991.

19 Martínez-CARDós Ruíz, El resarcimiento..., 61-69. 
El desarrollo reglamentario de ambas modificaciones fue acometido por el Real Decreto 673/1992, de 19 de junio, por el que se regulan los resarcimientos por daños a víctimas de bandas armadas y elementos terroristas ${ }^{20}$. En él se amplía la cobertura de las ayudas -incluyendo los daños personales, tanto físicos como psíquicos, los gastos por razón del tratamiento médico de los mismos y los daños materiales ocasionados en la vivienda habitual de las personas físicas que, como consecuencia o con ocasión de las actividades delictivas cometidas por bandas armadas o elementos terroristas, se causen a personas no responsables de dichas actividades ${ }^{21}$, limitándose, en contrapartida, la titularidad del derecho al resarcimiento de daños a quienes resulten más directamente afectados ${ }^{22}$, y se prevé un criterio uniforme para determinar el importe del resarcimiento ${ }^{23}$.

Este fue el régimen por el que se rigió el sistema de reparación pública a las víctimas de actos terroristas hasta la promulgación de la Ley 13/1996, de 30 de diciembre de Medidas fiscales, administrativas y de orden social ${ }^{24}$, por la que fueron derogados los números uno, dos y tres del art. 64 de la Ley 33/1987, la disposición adicional decimonovena de la Ley 31/1991 y los apartados segundo y tercero de la disposición adicional segunda de la Ley 35/1995, de 11 de diciembre, de ayudas y asistencia a las víctimas de delitos violentos y contra la libertad sexual ${ }^{25}$. Su Capítulo III (arts. 93 a 96) regula

${ }^{20}$ BOE núm. 156, de 30 de junio de 1992. MARTínEz-CARDós Ruíz, El resarcimiento..., 69-89.

${ }^{21}$ Art. 1.1 del Real Decreto 673/1992.

${ }^{22} \mathrm{Su}$ art. 5 disponía que «serán titulares del derecho de resarcimiento reconocido en el presente Real Decreto: 1.- En el caso de lesiones, la persona o personas que la hubieran padecido; 2.- En el caso de muerte, y con referencia siempre a la fecha de ésta, las personas que reúnan las condiciones que se indican a continuación: a) el cónyuge no separado legalmente $y$, siempre que dependieren económicamente de la persona fallecida, los hijos de ésta, cualquiera que sea su filiación y edad; b) en el caso de inexistencia de los anteriores, los padres de la persona fallecida cuando dependieran económicamente de ésta; c) en defecto de las anteriores, siempre que dependieran económicamente del fallecido y por orden sucesivo y excluyente, los nietos de la víctima cualquiera que sea su filiación, los hermanos y los abuelos de aquélla; d) de no existir ninguna de las personas reseñadas en los apartados anteriores, los hijos cualquiera que sea su filiación y edad, y los padres, que n. ${ }^{\circ}$ dependieran económicamente del fallecido».

23 Art. 6 del Real Decreto 673/1992.

${ }^{24}$ BOE núm. 315, de 31 de diciembre de 1996. Jaume SolÉ RIERA, La tutela de la victima en el proceso penal (Barcelona: J.M. ${ }^{a}$. Bosch Editor, 1997), 234-238.

${ }_{25}$ BOE núm. 296, de 12 de diciembre de 1995. Ello puso fin a la homogeneización del régimen compensatorio de todas las víctimas de delitos, habilitándose para tal fin al Gobierno para la modificación del régimen de resarcimientos por daños a las víctimas de bandas armadas y elementos terroristas, contemplado por el art. 64 de la Ley 33/1987, así como su desarrollo reglamentario conjunto, previstos en la Ley 35/1995. 
las ayudas a los afectados por delitos de terrorismo, determinando los daños resarcibles -los corporales y los materiales causados como consecuencia o con ocasión de delitos de terrorismo a quienes no fueren responsables de los mismos-, las normas por las que deben regirse y la competencia para el reconocimiento del resarcimiento contemplado, además, un régimen de subvenciones para las asociaciones cuyo objeto sea la representación y defensa de los intereses de las víctimas del terrorismo ${ }^{26}$. Su desarrollo se llevó a cabo por el Real Decreto 1211/1997, de 18 de julio de 1997, por el que aprobó el Reglamento de Ayudas y Resarcimientos a las Víctimas de Delitos de Terrorismo ${ }^{27}$.

Éste estuvo vigente hasta el 18 de marzo de 2003, fecha de entrada en vigor del Real Decreto 288/2003, de 7 de marzo, por el que se aprueba el Reglamento de ayudas y resarcimientos a las víctimas de delitos de terrorismo $^{28}$, que viene a continuar con la escala de mejora del sistema de ayudas públicas a las víctimas del terrorismo en que se ha concretado cada reforma o nueva norma ${ }^{29}$.

La última modificación en este ámbito ha sido operada por la Ley 29/2011, de 22 de septiembre, de Reconocimiento y Protección Integral a las Víctimas del Terrorismo ${ }^{30}$, que como explicita su Exposición de Motivos, viene a conformar «un cuerpo legal unitario que regula de manera unificada las prestaciones y ayudas económicas directas $[\ldots] »$. Se recogen en ella las

${ }^{26}$ SOLÉ RIERA, La tutela ..., 234-238.

27 BOE núm. 65, de 17 de marzo de 2003. Xulio Ferreiro BAAmonde, La víctima en el proceso penal (Madrid: La Ley, 2005), 558-561; Margarita RoIG ToRRES, La reparación del daño causado por el delito: aspectos civiles y penales (Valencia: Tirant lo Blanch, 2000), 327-333; LANDrove DíAZ, La moderna ..., 147-155. Según este último autor, con su aprobación se perseguía, no sólo mejorar cuantitativa y cualitativamente las ayudas a las víctimas de actos terroristas, sino también articular un programa de asistencia integral y personalizada para ellas.

28 BOE núm. 65, de 17 de marzo de 2003.

29 En el Anuario Estadístico del Ministerio del Interior, dentro del epígrafe relativo a «Otras actividades administrativas», hay un apartado rubricado como "Área de ayuda a las víctimas del terrorismo», en el que se contiene información sobre la distribución anual, por conceptos de daños indemnizados, de la cuantía de las ayudas y resarcimientos por terrorismo sufragadas cada año, tanto respecto del régimen ordinario como del régimen extraordinario.

${ }^{30}$ BOE núm. 229, de 23 de septiembre de 2011. Esta ley es la primera norma española que adapta y desarrolla las disposiciones contenidas en el Convenio Europeo sobre indemnización a las víctimas de delitos violentos de 1983, desde su entrada vigor en el estado español el 1 de febrero de 2002. Ignacio MuÑagORRI LAGUía y Ana Isabel PÉREZ MACHíO, "Aproximación al sentido y alcance del art. 8.2 del Convenio Europeo sobre indemnizaciones a víctimas de delitos violentos de 1983. Tensiones con el principio de legalidad», Revisa Vasca de Administración Pública, núm. especial 99-100 (2014): 2117. 
reparaciones, indemnizaciones y ayudas que se encontraban hasta ahora reguladas de forma separada en los Reales Decretos 288/2003, de 7 de marzo y 1912/1999, de 17 de diciembre ${ }^{31}$, que ordenaban, respectivamente el régimen de resarcimientos por daños derivados del atentado terrorista y el abono por parte del Estado, con carácter extraordinario, de la responsabilidad civil derivada de los delitos de terrorismo. Su desarrollo reglamentario se ha llevado a cabo por el Real Decreto 671/2013, de 6 de septiembre, por el que se aprueba el Reglamento de la Ley 29/201132.

\section{NUEVO RÉGIMEN GENERAL DE AYUDAS E INDEMNIZACIONES A LAS VÍCTIMAS DEL TERRORISMO: LA LEY 29/2011}

La ley 29/2011, de 22 de septiembre, de reconocimiento y protección integral a las víctimas del terrorismo, tiene por objeto «el reconocimiento de las víctimas del terrorismo y el establecimiento de un marco de indemnizaciones, ayudas, prestaciones, garantías y condecoraciones con la finalidad de reconocer y atenuar, en la medida de lo posible, las consecuencias de la acción terrorista en las víctimas y en sus familias o en las personas que hayan sufrido daños como consecuencia de la acción terrorista ${ }^{33}$. Así, se declaran como fines a perseguir mediante su promulgación, los siguientes ${ }^{34}$ : a) el reconocimiento y promoción de la dignidad y de la memoria de las víctimas del terrorismo; su protección integral; b) su resarcimiento, mediante las indemnizaciones y las ayudas previstas en esta ley, de los daños personales y materiales sufridos como consecuencia de la acción terrorista; c) el fortalecimiento de las medidas de atención; el reconocimiento de los derechos de las víctimas del terrorismo; d) el establecimiento de mecanismos de flexibilización y coordinación en el conjunto de trámites administrativos que son precisos para obtener las indemnizaciones, ayudas y prestaciones previstas en la Ley; e) el establecimiento de un marco específico en el tratamiento procesal; f) el reconocimiento y apoyo a las personas objeto de amenazas y coacciones de los grupos terroristas y de su entorno.

Pues bien, de entre todas estas finalidades nosotros centraremos nuestra atención en el nuevo régimen indemnizatorio y de ayudas a las víctimas de

31 BOE núm. 305, de 22 de diciembre de 1999.

32 BOE núm. 224, de 19 de septiembre de 2013. En el periodo comprendido entre la entrada en vigor de la Ley 29/2011 -23 de septiembre de 2011-y la entrada en vigor del Real Decreto 671/2013 -19 de septiembre de 2013- siguió vigente la anterior normativa en todo aquello que no se oponía y no estaba regulada en la nueva ley.

33 Art. 1 de la Ley 29/2011.

34 Art. 2.2 de la Ley 29/2011. 
terrorismo articulado en el Título III de esta ley. En él se ha procedido a unificar las prestaciones que, hasta el momento, eran reguladas de manera diferenciada en las diversas normas a las que hemos referencia anteriormente.

\subsection{Previsiones generales}

\subsubsection{Naturaleza jurídica}

Las posturas que tradicionalmente se han sustentado con respecto al fundamento de la compensación estatal han sido dos: la que la concibe como una responsabilidad patrimonial del Estado derivada del incorrecto funcionamiento de sus servicios, de un lado, y la que la considera como una manifestación de los principios de solidaridad social y de equidad, de otro ${ }^{35}$. En el primer caso se predicaría una naturaleza indemnizatoria de esta compensación estatal, en tanto que, conforme a la segunda de las posturas, estaríamos ante una ayuda pública concedida por el Estado de manera graciosa.

El legislador español ha optado por la segunda de las construcciones al señalar, en la exposición de motivos de la Ley 35/1995, de 11 de diciembre, que «no cabe admitir que la prestación económica que el Estado asume sea una indemnización, ya que éste no puede asumir sustitutoriamente las indemnizaciones debidas por el culpable del delito $[\ldots] »^{36}$.

${ }^{35}$ Ferreiro BaAmonde, La víctima en..., 522; RoIg Torres, La reparación del daño..., 338, nota 117 .

${ }^{36}$ Ello también ha sido confirmado por la jurisprudencia, siendo la primera de ellas la STS 1579/1997, de 19 de diciembre, en cuyo FJ 6. ${ }^{\circ}$ establece que «[...] el concepto legal de ayudas públicas, contemplado en esta Ley debe distinguirse de figuras afines y, señaladamente, de la indemnización. No cabe admitir que la prestación económica que el Estado asume, sea una indemnización, ya que, éste no puede asumir sustitutoriamente las indemnizaciones debidas por el culpable del delito ni, desde otra perspectiva, es razonable incluir el daño moral provocado por el delito. La Ley por el contrario, se construye sobre el concepto de ayudas públicas - plenamente recogido en nuestro ordenamiento- referido directamente al principio de solidaridad en que se inspira». Como pone de relieve RoIG TORRES, La reparación del daño..., 338-339, ello determina que las disposiciones de la Ley 35/1995 no sean aplicables, ni afecten, a la responsabilidad civil del delito así como que la concesión de estas ayudas se circunscriba exclusivamente a los delitos violentos y dolosos. Autores como SolÉ RIERA, La tutela de la víctima ..., 212-215, se postulan a favor de considerar la compensación estatal como un deber del estado ostentando ésta, en consecuencia, naturaleza indemnizatoria, si bien es consciente de que no es éste el criterio seguido por el legislador. En este mismo sentido se pronuncia FERREIRO BAAMONDE, La víctima en ..., 524-525, para quien desde un plano teórico sería perfectamente factible la exigencia al Estado del resarcimiento de los daños causados por su falta de diligencia en la protección de sus ciudadanos, en la medida en que al asumir la protección del orden público ostenta una situación de garante respecto de éste. 
Nos hallamos, pues, ante una obligación prestacional asistencial que el Estado se impone a sí mismo, en aras a socializar el riesgo derivado de la delincuencia violenta y sexual como muestra de solidaridad con las víctimas. Más explícitamente la Circular FGE 2/1998, de 27 de octubre, cataloga a estas ayudas como un tertium genius o figura sui generis de obligación resarcitoria de naturaleza especial que el Estado se impone a sí mismo, y que no puede identificarse, ni con la responsabilidad patrimonial de las Administraciones públi$\operatorname{cas}^{37}$, ni con las prestaciones asistenciales de la Seguridad Social ${ }^{38}$. Hablamos, en suma, de un derecho de previsión legislativa ${ }^{39}$, cuyo fundamento se encuentra en los principios de equidad y solidaridad social. Esta misma naturaleza es predicable respecto del régimen general de ayudas y resarcimientos a las víctimas del terrorismo ${ }^{40}$, pese a que en los arts. 20 y 21 de la Ley 29/2011 sí se articula un auténtico sistema indemnizatorio, pero sin que ello implique la asunción por el Estado de responsabilidad subsidiaria alguna ${ }^{41}$.

\subsection{2. Ámbito subjetivo}

Las ayudas e indemnizaciones previstas en esta ley serán de aplicación a aquellas personas, independientemente de su nacionalidad, que, como consecuencia de una acción terrorista, sufran, directamente, daños físicos, psíquicos y/o materiales, fallezcan o sean amenazadas o acrediten sufrir coacciones directas y reiteradas procedentes de organizaciones terroristas ${ }^{42}$. En el supuesto de fallecimiento de la víctima, ostentarán esta titularidad las personas que, por razón de parentesco, convivencia o relación de dependencia, se hayan concretadas en el art. 17 de la Ley $29 / 2011^{43}$.

${ }^{37}$ De acuerdo con el art. 106.2 CE «los particulares, en los términos establecidos por la ley, tendrán derecho a ser indemnizados por toda lesión que sufran en cualquiera de sus bienes y derechos, salvo en los casos de fuerza mayor, siempre que la lesión sea consecuencia del funcionamiento de los servicios públicos»».

${ }^{38}$ Conforme al art. $41 \mathrm{CE}$, «los poderes públicos mantendrán un régimen público de Seguridad Social para todos los ciudadanos que garantice la asistencia y prestaciones sociales suficientes ante situaciones de necesidad [...]».

39 SOLÉ RIERA, La tutela de la víctima ..., 225-226.

40 STS (Sala de lo Contencioso-Administrativo) núm. de recurso 1439/1995, de 1 de junio de 1999; Herrera Moreno, Myriam, La hora de la víctima. Compendio de Victimología (Madrid: Edersa, 1996), 291-292, para quien la Ley 35/1995 solventa cualquier duda al respecto de su naturaleza residiendo las diferencias entre un régimen y otro en «la percepción estatal de una especial solidaridad y concienciación de nuestra sociedad ante las víctimas de terrorismo que obliga así, al establecimiento de privilegios y prioridades en la distribución de los recursos públicos [...]».

${ }^{41}$ Art. 20.7 de la Ley 29/2011.

42 Art. 4 de la Ley 29/2011.

${ }^{43}$ Punto 2.2.1.1.1 del presente artículo. 
Por acción terrorista se entiende, a este respecto, aquélla que es perpetrada por personas integradas en organizaciones o grupos criminales que tengan por finalidad o por objeto subvertir el orden constitucional o alterar gravemente la paz pública, así como por personas que, sin estar integradas en dichas organizaciones o grupos criminales, persigan con sus actos idénticos fines ${ }^{44}$.

No obstante, para su efectivo otorgamiento, se requiere la concurrencia, a mayores, de alguno de los dos siguiente supuestos ${ }^{45}$ : a) la existencia de una sentencia firme en que se reconozca su derecho a ser indemnizado en concepto de responsabilidad civil por los hechos y daños contemplados en esta Ley; b) la realización de las oportunas diligencias judiciales o la incoación del correspondiente proceso penal para el enjuiciamiento de la acción terrorista sufrida ${ }^{46}$.

La concesión de las ayudas y prestaciones aquí contempladas se someterá, en todo caso, «a los principios que, para ser indemnizadas, se establecen en el Convenio Europeo sobre indemnización a las víctimas de delitos violentos $\gg{ }^{47}$. Pues bien, de entre los principios del citado Convenio contemplados en su Título I (arts. 1-11), queremos llamar la atención sobre la excepción contemplada en el art. 8.2 $2^{48}$. Dicho precepto habilitada para que los Estados puedan reducir o suprimir las correspondientes indemnizaciones a aquellas víctimas que hayan participado en la delincuencia organizada o pertenezcan a un grupo dedicado a la comisión de delitos violentos.

Haciendo uso de dicha facultad potestativa, el gobierno ha optado por la solución extrema excluyendo de su ámbito de aplicación a los miembros de ETA que han sido víctimas de los GAL, del Batallón Vasco Español o de la Triple A -grupos parapoliciales contraterroristas y de extrema derecha que

${ }^{44}$ Art. 3 de la Ley 29/2011.

45 Art. 3 bis de la Ley 29/2011, introducido por la Ley 17/2012, de 27 de diciembre, de Presupuestos Generales del Estado para el año 2013. BOE núm. 312, de 28 de diciembre de 2012.

${ }^{46}$ En estos casos, ante la inexistencia de una sentencia firme condenatoria, la acreditación ante el órgano competente de la Administración General del Estado de la condición de víctima o derechohabiente, la entidad de los daños sufridos, la naturaleza de los actos o hechos causantes y los demás requisitos legalmente exigidos se realizará por cualquier medio de prueba admisible en derecho.

47 Art. 3 bis. 2 de la Ley 29/2011, introducido por la Ley 17/2012, de 27 de diciembre, de Presupuestos Generales del Estado para el año 2013. BOE núm. 312, de 28 de diciembre de 2012. Es ésta la primera referencia que se contiene en una norma española a la Convenio de 1983 desde su ratificación por España en el 2002. MuñaGORRI LAGUía y PÉREZ MACHío, «Aproximación al sentido y alcance del art. 8.2», 2118.

48 En cuanto al sentido y alcance de las excepciones del citado precepto, MUÑAGORRI LAGUÍA y PÉREZ MACHÍO, «Aproximación al sentido y alcance del art. 8.2», 2110-2116. 
actuaron en España, básicamente, entre 1976 y 1986- ${ }^{49}$. Las resoluciones del Ministerio del Interior dictadas a este respecto han venido siendo ratificadas por la sección 5. ${ }^{\mathrm{a}}$ de lo Contencioso-Administrativo de la Audiencia Nacional ${ }^{50}$.

La válida exclusión requerirá, en todo caso, en nuestra opinión, de la concurrencia de dos requisitos:

a) que conste acreditada de forma fehaciente la pertenencia de la víctima a una organización de delincuencia organizada o grupo dedicado a la comisión de delitos violentos. La correcta observancia del principio de legalidad y del derecho a tutela judicial efectiva nos lleva a concluir que la atribución a la víctima de alguno de los delitos comprendidos en los arts. 571 y ss. CP sólo puede ser realizada mediante sentencia judicial firme ${ }^{51}$;

b) que la condición de víctima de terrorismo se haya adquirido con posterioridad a la entrada en vigor del art. 3 bis.2 de la Ley 29/2011 -1 de enero de 2013- que desarrolla, de forma expresa, en nuestro

${ }^{49}$ Resoluciones R/2012/2165, de 9 de octubre de 2013; R/2012/2170, de 11 de septiembre de 2013; R/2012/2188, de 11 de septiembre de 2013; R/2012/2172, de 2 de agosto de 2013; R/2012/2171, de 13 de junio de 2013.

${ }^{50}$ SSAN núm. 251/2015, de 23 de septiembre; núm. 224/2015, de 15 de julio; núm. 223/2015, de 15 de julio; núm. 193/2015, de 1 de julio; núm. 195/2015, de 1 de julio; núm. 192/2015, de 1 de julio; núm. 175/2015, de 24 de junio; núm. 174/2015, de 24 de junio; núm. 173/2015, de 24 de junio; núm. 172/2015, de 24 de junio; núm. 170/2015, de 24 de junio; núm. 165/2015, de 24 de junio; núm. 162/2015, de 24 de junio; núm. 161/2015, de 24 de junio.

${ }_{51}$ De esta opinión, MuÑagorri Laguía y Pérez Machío, «Aproximación al sentido y alcance del art. 8.2», 2112-2114 y 2120-2123, a cuyo juicio, la existencia de meros indicios carece «de la eficacia jurídica necesaria para desvirtuar el principio de presunción de inocencia (entiéndase por tales la presencia de meros indicios en informes policiales que pueden llegar a fundamentar, en un momento determinado, la detención o imputación de una persona, sin que exista sentencia condenatoria firme) vulneran el principio de legalidad, la presunción de inocencia y la tutela judicial efectiva, así como la división de poderes, en que se fundamenta el principio de legalidad, resultando tan infundada extensión, manifiestamente arbitraria». Por su parte, la SAN núm. 224/2015, de 15 de julio, dispone a este respecto, en su FJ $4 .^{\circ}$, que «es principio jurídico procesal que los órganos jurisdiccionales gozan de competencia para valorar y apreciar el supuesto de hecho en los que se asienta la consecuencia jurídica de la norma jurídica que han de aplicar para resolver la cuestión jurídica sometida a su conocimiento, sin perjuicio del principio general que los hechos declarados probados en sentencia penal firme son de obligado respeto por el resto de los tribunales de justicia de los restantes órdenes jurisdiccionales. Pero ante la ausencia de pronunciamiento penal, los tribunales de justicia gozan, a la vista de las pruebas existentes en el proceso, de la facultad de determinar los datos fácticos en los que se asienta la proyección de la norma jurídica que están llamados a aplicar $[\ldots]$... 
ordenamiento, la excepción potestativa contemplada en el art. 8.2 del Convenio. Una interpretación en sentido contrario vulneraría la exigencia constitucional de la irretroactividad de las disposiciones restrictivas de derechos individuales (art. 9.3 CE) ${ }^{52}$.

\subsection{3. Ámbito espacial}

Por lo que respecta a su ámbito de aplicación espacial, éste viene delimitado en su art. 6, resultando de aplicación no sólo a los actos terrorista cometidos en territorio español o bajo jurisdicción española, sino también con respecto a los actos terroristas cometidos fuera del territorio nacional del que sean víctimas personas de nacionalidad española. Esta previsión representa una excepción al principio de territorialidad que con carácter general rige en las leyes sobre compensación estatal ${ }^{53}$, que viene complementado en este caso, como se establece en su Exposición de motivos, por el principio de ciudadanía. En este sentido se distinguen tres supuestos ${ }^{54}$ : a) personas de nacionalidad española que sean víctimas en el extranjero de grupos que operen habitualmente en España o de acciones terroristas dirigidas a atentar contra el Estado español o los interese españoles; b) a los participantes en operaciones de paz y seguridad que formen parte de los contingentes de

52 En este sentido se pronuncian MuÑagorRi Laguía y Pérez Machío, «Aproximación al sentido y alcance del art. 8.2», 2115-2116, p. 2118 y 2123-2127, para quienes la eficacia jurídica de las excepciones del citado precepto, en el ámbito del ordenamiento español, se condiciona a la concurrencia de dos presupuestos: en primer lugar, a la entrada en vigor del instrumento de ratificación interno y, en segundo lugar, «al desarrollo normativo expreso y motivado del concreto contenido del indicado precepto». Y ello porque, en su opinión, «[...] no se debe olvidar que este artículo, lejos de contemplar un mandato internacional de cumplimiento obligatorio, prevé una disposición de naturaleza potestativa que puede o no ser atendida por el Estado concreto y que precisará, ahora sí, de una referencia expresa y motivada a la misma en el ámbito del Ordenamiento jurídico interno». Otra opinión es la que sostiene la jurisprudencia evidenciada, entre otras, en la SAN núm. 161/2015, de 24 de junio, conforme a la que «desde el 1 de febrero de 2002 el repetido Convenio forma parte del ordenamiento jurídico español y, en consecuencia, es plenamente aplicable, por lo que su empleo en resoluciones administrativas dictadas con posterioridad a esa fecha y referidas a supuestos que entran en su ámbito de aplicación», con independencia - continúa diciendo la sentencia- de que «faltara una remisión expresa (al Convenio) en la Ley 29/2011 o una prevención específica al respecto».

${ }_{53}$ Esta previsión representa una excepción al principio de territorialidad que con carácter general rige en las leyes sobre compensación estatal, que viene complementado en este caso, como se establece en su Exposición de motivos por el principio de ciudadanía.

${ }^{54}$ Arts. 6.2 de la Ley 29/2011 y 2.2 y 3 del Real Decreto 671/2013. 
España en el exterior y sean objeto de un atentado terrorista ${ }^{55}$; c) españoles víctimas de acciones terroristas cometidas fuera del territorio nacional, en que no concurran las circunstancias anteriores. No obstante, la ley no trata estos tres supuestos de forma igualitaria estableciéndose, como veremos, diferencias en cuanto a la cuantía de la indemnización y los daños indemnizables.

\subsection{4. Ámbito temporal}

Las disposiciones de la presente ley serán de aplicación a aquellos actos terroristas que tengan lugar con posterioridad al 1 de enero de 1960, fecha en la que falleció la primera víctima de $\mathrm{ETA}^{56}$. Asimismo, se prevé la aplicación retroactiva de la ley en relación con aquellos casos en los que, con anterioridad a la entrada en vigor de esta ley ${ }^{57}$, las víctimas hubieran recibido, en concepto de ayudas o indemnizaciones, cuantías inferiores a las establecidas en aquélla ${ }^{58}$.

En ambos casos, el plazo para la solicitud de los resarcimientos, las indemnizaciones y ayudas contempladas en esta Ley será de un año, a contar desde la entrada en vigor del Real Decreto 671/2013 ${ }^{59}$.

\subsubsection{Régimen de compatibilidad}

Las ayudas e indemnizaciones aquí establecidas son compatibles con las pensiones, ayudas y compensaciones que pudieran reconocerse tanto en virtud de la presente ley como las que pudieran dictar las Comunidades Autónomas $^{60}$. Igualmente, serán compatibles con la exigencia de responsabilidad

${ }^{55}$ Conforme al art. 2.4 del Real Decreto 671/2013, se entenderán comprendidos en este supuesto: a) los miembros de las Fuerzas Armadas españolas que participen en dichas operaciones, con inclusión de aquellos que, dependientes del Ministerio de Defensa, formen parte de la tripulación de los medios de transporte en los que se realicen los desplazamientos; b) los miembros de las FFCCSE que participen en dichas operaciones: c) el personal al servicio de las Administraciones Públicas, incluyendo el contratado en España a título individual por el Estado, que se desplace al territorio en que se realice la operación para participar en ella o que se encuentre destinado en dicho territorio.

${ }_{56}$ Arts. 7 de la Ley 29/2011 y 2.4 del Real Decreto 671/2013.

${ }^{57}$ En atención a lo dispuesto en la Disposición Final Quinta, su entrada en vigor tuvo lugar el 24 de septiembre de 2011.

58 Disposición Adicional Primera de la Ley 29/2011 y Disposición Transitoria Segunda del Real Decreto 671/2013.

${ }_{59} \mathrm{Su}$ entrada en vigor tuvo lugar el 19 de septiembre de 2013.

${ }^{60}$ Art. 15.1 de la Ley 29/2011. Hasta el momento, un total de ocho Comunidades Autónomas han aprobado normativa autonómica en materia de víctimas de terrorismo: a) Ley 10/2010, de 15 de noviembre, relativa a medidas para la asistencia y atención a 
patrimonial al Estado por el normal o anormal funcionamiento de la Administración, si bien aquéllas se imputarán a la indemnización que pudiera reconocerse por este concepto, detrayéndose de la misma ${ }^{61}$.

\subsubsection{Exenciones}

Las cantidades percibidas en el marco de esta ley están exentas de cualquier impuesto personal que pudiera recaer sobre ellas ${ }^{62}$.

\subsubsection{Actualización de la cuantía resarcitoria}

La cuantía de las ayudas e indemnizaciones previstas en esta ley será actualizada conforme a las previsiones contenidas en las leyes anuales de Presupuestos Generales del Estado ${ }^{63}$.

\subsection{Regímenes de ayuda a las víctimas de terrorismo}

\subsubsection{Régimen ordinario de ayuda a las víctimas del terrorismo}

El principio de solidaridad alcanza su máxima expresión en la regulación de este régimen ordinario de las ayudas a las víctimas del terrorismo al exigirse, únicamente, como título habilitador para su otorgamiento, la mera condición de víctima. No se requiere, por tanto, que medie una sentencia firme en que se les reconozca el derecho a ser indemnizados en concepto de responsabilidad civil por los hechos y daños a los que esta ley resulta de

las víctimas del terrorismo (Andalucía); b) Ley 4/2008, de 17 de junio, de medidas a favor de las Víctimas del Terrorismo (Aragón); c) Ley 6/2005, de 27 de diciembre, de medidas para la asistencia y atención de las víctimas del terrorismo y de creación del Centro Extremeño de Estudios para la Paz (Extremadura); d) Ley 7/2009, de 2 de noviembre, de ayuda a las víctimas del terrorismo (Región de Murcia); e) Ley 12/1996, de 19 de diciembre, de Ayudas a las Víctimas del Terrorismo (Madrid); f) Ley Foral 9/2010, de 28 de abril, de ayuda a las víctimas del terrorismo (Navarra); g) Ley 4/2008, de 19 de junio, de Reconocimiento y Reparación a las Víctimas del Terrorismo (País Vasco); h) Ley 1/2004, de 24 de mayo, de Ayuda a las Víctimas del Terrorismo (Comunidad Valenciana). Un estudio detallado sobre esta normativa autonómica puede ser consultado en Antonio Vicente Sempere Navarro y Djamil Tony Kahale Carrillo (coords.), Reconocimiento y protección integral de las víctimas del terrorismo (Madrid: Eolas, 2014), 229-535; María José Castañón Álvarez, Víctimas del terrorismo: Protección y tutela (Granada: Comares, 2013), 68-74.

${ }^{61}$ Art. 15.2 de la Ley 29/2011.

${ }_{62}$ Art. 16 de la Ley 29/2011.

${ }^{63}$ Disposición Adicional Séptima de la Ley 29/2011. 
aplicación. Tampoco que se reserve acción de repetición alguna por parte del Estado. Sólo se requiere la acreditación del nexo causal entre las actividades delictivas terroristas y el resultado lesivo producido, extremo que se llevará a cabo a través de la valoración de las pruebas aportadas o practicadas en la instrucción del expediente administrativo indemnizatorio ${ }^{64}$.

Los daños producidos como consecuencia de un acto terrorista que pueden ser objeto de resarcimiento por el Estado son delimitados en las secciones II y III del Capítulo II del Título III de la Ley. En este sentido, en el texto legal se alude a los daños personales y a los daños materiales.

\subsubsection{Daños personales}

La indemnización por daños personales derivados de actos de terrorismo es regulada en los arts. 17 a 22 de la presente ley. En el concepto de daños personales se engloban tanto los daños físicos como los psíquicos siendo, no obstante, únicamente indemnizables por el Estado, aquéllos que den lugar a un fallecimiento, una gran invalidez, una incapacidad permanente absoluta, una incapacidad permanente total, una incapacidad permanente parcial o lesiones permanentes no invalidantes; asimismo, también resultan indemnizables los actos de secuestro ${ }^{65}$. La principal nota diferenciadora de las indemnizaciones por daños personales es su compatibilidad con cualesquiera otras ayudas a que tuvieran derecho la víctima o sus causahabientes. Las características y peculiaridades propias de cada una de las modalidades indemnizatorias por daños personales hacen necesario su estudio autónomo.

\subsection{Fallecimiento}

Los titulares del derecho resarcitorio cuando como consecuencia de la actividad delictiva se produce el fallecimiento de la víctima directa serán, por orden de preferencia ${ }^{66}$ : a) el cónyuge de la persona fallecida, si no estuviera separado legalmente, o la persona con la que hubiera venido conviviendo con ella de forma permanente con análoga relación de afectividad durante, al menos, los dos años anteriores al momento del fallecimiento, salvo que hubieran tenido descendencia en común, en cuyo caso bastará la mera convivencia; y los hijos de la persona fallecida; b) en ausencia de los anteriores, serán destinatarios de dichas ayudas, por orden sucesivo y excluyente, los padres, los nietos, los hermanos y los abuelos de la persona fallecida; c) y, finalmente, en defecto de todos los sujetos anteriores, siempre y cuando

${ }^{64}$ Samuel Serrano Galvís, Reparación de los daños causados por el terrorismo (tesis doctoral, Universidad de Salamanca, 2009), 76-81.

65 Art. 18 de la Ley 29/2011.

${ }^{66}$ Arts. 17.2 de la Ley 29/2011 y 6.1 del Real Decreto 671/2013. 
dependieran económicamente de la persona fallecida ${ }^{67}$, los hijos de la persona conviviente y los menores en acogimiento familiar permanente.

La ley ha articulado un sistema de distribución de la indemnización para los casos de concurrencia de varios beneficiarios ${ }^{68}$. Así, en el primero de los supuestos, la cuantía se repartirá por mitades, correspondiendo una al cónyuge no separado legalmente o conviviente y otra a los hijos, distribuyéndose esta última entre ellos por partes iguales ${ }^{69}$. En el segundo caso, la cuantía se repartirá por partes iguales entre las personas con el mismo parentesco. Por último, de resultar beneficiarios los hijos de la persona conviviente y los menores en acogimiento familiar permanente, el reparto se llevará a cabo entre ellos a partes iguales.

Por lo que respecta a la cuantificación de la indemnización por fallecimiento, ésta asciende a $250.000 €$. A esta cuantía se le aplicará un coeficiente corrector que tiene por objeto la toma en consideración en la determinación del montante indemnizatorio final de las cargas familiares de la persona fallecida. En este sentido, dicha cantidad se verá incrementada en una cantidad fija de veinte mensualidades del Indicador Público de Renta de Efectos Múltiples (en adelante IPREM) que corresponda ${ }^{70}$, en razón de cada uno de los hijos o menores acogidos que dependiesen económicamente de la víctima ${ }^{71}$.

${ }^{67}$ Conforme al art. 6.3 del Real Decreto 671/2013 «se entenderá que una persona depende económicamente del fallecido cuando, en el momento del fallecimiento, viviera total o parcialmente a expensas de éste y no percibiera en cómputo anual rentas o ingresos de cualquier naturaleza superiores al 150 por ciento del IPREM que correspondiera en aquel momento, también en cómputo anual».

68 Arts. 17.3 y 4 de la Ley 29/2011 y 6.2 del Real Decreto 671/2013.

${ }^{69}$ El legislador no ha contemplado el supuesto de concurrencia entre el cónyuge no separado legalmente y el conviviente. En los arts. 7.3.a) del Real Decreto 288/2003 y 14.1 del Real Decreto 1912/1999 se disponía, a este respecto, que la condición de beneficiario la ostentaría, en estos supuestos, el cónyuge no separado legalmente.

70 Desde el año 2010 la cuantía del IPREM anual se halla congelado ascendiendo su cuantía a $6.390,13 €$.

${ }^{71}$ Arts. 19 de la Ley 29/2011 y 7 del Real Decreto 671/2013. El Real Decreto $288 / 2003$, de 7 de marzo, por el que se aprueba el Reglamento de ayudas y resarcimientos a las víctimas de delitos de terrorismo, preveía, además, en su art. 8.7. ${ }^{\mathrm{a}}$, un factor de corrección que permitía incrementar, en un $30 \%$, las cantidades establecidas como resarcimiento en casos de fallecimiento, incapacidades permanentes, lesiones no permanentes invalidantes e incapacidades temporales atendiendo a las circunstancias o situaciones de especial dificultad o necesidad, personales, familiares, económicas y profesionales de la víctima. Luis RocA AGAPITO, "Análisis del nuevo régimen jurídico-económico de las víctimas del terrorismo», Diario La Ley, n. ${ }^{\circ} 7776$ (2012), 10, defendía la inclusión de una previsión del mismo tenor en el desarrollo reglamentario de la ley, sin que ello haya sido, finalmente, observado. 
Asimismo, se procederá a abonar los gastos de traslado, sepelio e inhumación o incineración de la persona fallecida como consecuencia de un atentado terrorista, siempre que ello no se halle cubierto por un póliza de seguro y, en todo caso, hasta el límite de $6.000 €^{72}$.

\subsection{Incapacidad permanente}

Las víctimas que, como consecuencia de los daños físicos o psíquicos derivados de un acto terrorista, sufran una incapacidad permanente tendrán derecho a las siguientes indemnizaciones, moduladas en función de la gravedad de la incapacidad ${ }^{73}$ : a) gran invalidez (500.000€); b) incapacidad permanente absoluto (180.000€); c) incapacidad permanente total (100.000€); d) incapacidad permanente parcial (75.000€).

Al igual que con relación a la indemnización por fallecimiento, su cuantía verá incrementada en una cantidad fija de veinte mensualidades del IPREM que corresponda, en razón de cada uno de los hijos o menores acogidos que dependiesen económicamente de la víctima ${ }^{74}$.

\subsection{Lesiones permanentes no invalidantes}

Las indemnizaciones por lesiones permanentes no invalidantes, correspondientes a las personas que hayan sufrido daños físicos y/o psíquicos como consecuencia de un acto terrorista, se determinarán, de un lado, conforme al Real Decreto Legislativo 8/2004, de 29 de octubre, por el que se aprueba el Texto Refundido de la Ley sobre Responsabilidad Civil y Seguro en la Circulación de Vehículos a Motor ${ }^{75} \mathrm{y}$, de otro, con arreglo al baremo resultante de la aplicación de la legislación de seguridad social sobre cuantías de las indemnizaciones de las lesiones, mutilaciones y deformaciones definitivas y no invalidantes, causadas por accidente de trabajo o enfermedad profesional $^{76}$.

\subsection{Incapacidad temporal}

Los beneficiarios de esta indemnización serán las personas que hayan sufrido daños físicos o psíquicos como consecuencia de un acto terrorista,

${ }^{72}$ Art. 8 del Real Decreto 671/2013.

73 Arts. 18 de la Ley 29/2011y 6.1 del Real Decreto 671/2013.

${ }^{74}$ Arts. 19 de la Ley 29/2011 y 10.2 del Real Decreto 671/2013. Critica RocA AGAPITO, «Análisis del nuevo régimen», 10, que únicamente se haya previsto este factor de corrección con respecto a los supuestos de fallecimiento e incapacidad permanente, abogando por su extensión, en el desarrollo reglamentario de la ley, a los casos de lesiones permanente no invalidantes y de incapacidades temporales, hecho que no ha sucedido.

75 BOE núm. 267, de 5 de noviembre de 2004.

76 Arts. 18 de la Ley 29/2011 y 10.1.e del Real Decreto 671/2013. 
determinándose su cuantía mediante la multiplicación por dos del IPREM por cada día que permanezca la lesión, hasta el límite de 18 mensualidades ${ }^{77}$.

\subsection{Secuestro}

Aquellas personas que hayan sido víctimas de un secuestro por actos terroristas tendrán también derecho a ser indemnizados ${ }^{78}$. Procederá el abono de $12.000 €$ por el acto del secuestro y el triple del IPREM diario por cada día de duración del mismo, hasta el límite de la indemnización establecida por incapacidad permanente parcial, fijada en $75.000 €^{79}$.

\subsection{Ayudas excepcionales por daños personales sufridos en el extranjero}

Una de las principales novedades introducidas por la presente ley es la ampliación del ámbito de cobertura a aquellas víctimas de nacionalidad española que han sufrido actos terroristas fuera del territorio español.

Este régimen excepcional será de aplicación, únicamente, a las víctimas de nacionalidad española en que no concurran las circunstancias descritas en el art. 6.2 de la ley ${ }^{80}$, a saber: que la acción terrorista hubiera sido perpetrada por grupos que operan habitualmente en España; que dicha acción estuviera dirigida atentar contra el Estado español o los intereses españoles; que se trate de participantes en operaciones de paz y seguridad que formen parte de los contingentes de España en el exterior.

La indemnización, en este supuesto, se limita a los daños personales que sufran como consecuencia de un acto terrorista y que den lugar a fallecimiento, gran invalidez, incapacidad permanente absoluta, incapacidad permanente total, incapacidad permanente parcial, lesiones invalidantes y secuestro ${ }^{81}$.

Por lo que respecta a la cuantificación de la indemnización a recibir, la ley diferencia según la víctima tenga su residencia habitual en el país en que se haya producido la acción terrorista o no la tenga. En el primer supuesto, la víctima percibirá el $50 \%$ de las cantidades fijadas en el régimen general de indemnización por daños personales ${ }^{82}$; en tanto que en el segundo, ese porcentaje se reduce al $40 \%{ }^{83}$.

77 Arts. 18 de la Ley 29/2011 y 10.1.f del Real Decreto 671/2013.

78 Arts. 18 de la Ley 29/2011 y 13 del Real Decreto 671/2013.

79 Art. 14 del Real Decreto 671/2013.

${ }^{80}$ De concurrir estas circunstancias se aplicaría, como hemos visto, el régimen general de ayudas, prestaciones e indemnizaciones.

81 Arts. 22 de la Ley 29/2011 y 20 del Real Decreto 671/2013.

82 Arts. 22.1 de la Ley 29/2011 y 21.1 del Real Decreto 671/2013.

${ }^{83}$ Arts. 22.1 de la Ley 29/2011 y 21.2 del Real Decreto 671/2013. 
Esta ayuda económica tendrá carácter subsidiario con respecto a las compensaciones que puedan ser otorgadas a la víctima por el país en que se haya producido el atentado. En aquellos supuestos en los que la indemnización recibida desde aquél sea inferior a la que le correspondería en virtud de la aplicación de esta ley, la víctima podrá solicitar el abono de la diferencia ${ }^{84}$.

\subsubsection{Daños materiales}

En la sección 2. ${ }^{a}$ del Capítulo II se regula el resarcimiento por daños materiales, que comprenderán, los causados en las viviendas de las personas físicas, en los establecimientos mercantiles, industriales o en elementos productivos de las empresas, en las sedes de partidos políticos, sindicatos u organizaciones sociales y los producidos en vehículos ${ }^{85}$. No están incluidos en su ámbito de aplicación los daños causados en bienes de titularidad pública ${ }^{86}$.

Los beneficiarios de esta indemnización serán las personas que sufran los daños materiales, siempre que no fueran responsables de aquéllos ${ }^{87}$. No obstante, la Administración General del Estado podrá encargar la reparación de los inmuebles afectados por la acción terrorista a empresas constructoras o a otras Administraciones Públicas, siendo en este caso abonado a éstas el importe de la indemnización. En estos supuestos, los damnificados no podrán reclamar al Consorcio de Seguros las indemnizaciones correspondientes a los daños reparados en los bienes asegurados, las cuales serán percibidas por la empresa ejecutora de las obras o por la Administración actuante mediante convenio, conforme a las peritaciones oficiales de dicho Consorcio ${ }^{88}$.

Estos resarcimientos tendrán carácter subsidiario respecto de los reconocidos por las Administraciones Públicas o derivados de contratos de seguro, reduciéndose en la cantidad recibida por estos conceptos y sin que, en ningún caso, en su conjunto, puedan superar el valor del daño producido ${ }^{89}$.

\subsection{Vivienda habitual}

Las personas físicas que, como consecuencia de un acto terrorista, sufran daños en su vivienda habitual ${ }^{90}$ tendrán derecho a ser resarcidas por aquéllos que afecten a la estructura, las instalaciones y el mobiliario, y cuya reposi-

${ }^{84}$ Arts. 22.2 de la Ley 29/2011 y 22 del Real Decreto 671/2013.

85 Arts. 23.2 de la Ley 29/2011 y 23.1 del Real Decreto 671/2013.

${ }^{86}$ Arts. 23.4 de la Ley 29/2011 y 23.3 del Real Decreto 671/2013.

87 Art. 23.1 de la Ley 29/2011.

88 Art. 23.2 de la Ley 29/2011.

89 Arts. 23.3 de la Ley 29/2011 y 23.2 del Real Decreto 671/2013.

${ }^{90}$ Conforme al art. 24.2 del Real Decreto 671/2013, por vivienda habitual se entenderá «[...] la edificación que constituya la residencia de una persona o unidad familiar durante un período de al menos seis meses al año. Igualmente se entenderá que la vivienda es habitual en los casos de ocupación de ésta desde tiempo inferior a un año, siempre que 
ción resulte necesaria para que la vivienda recupere las condiciones previas de habitabilidad ${ }^{91}$.

Si la vivienda no tiene carácter de residencia habitual el resarcimiento comprenderá el $50 \%$ de los daños sufridos, siendo el límite actual de $113.680 €^{92}$. Asimismo, también podrá contribuirse al abono de los gastos generados como consecuencia de tener que abandonar temporalmente su vivienda mientras se efectúan las obras de reparación ${ }^{93}$. Para ello, la Administración General del Estado podrá celebrar convenios con otras administraciones públicas o con organizaciones especializadas en el auxilio o asistencia a damnificados en situaciones de siniestro o catástrofe, en el cual se fijarán el porcentaje de la contribución de las partes a los gastos de alojamiento así como el límite temporal cubierto por estas ayudas ${ }^{94}$. En defecto de dicho convenio, la Administración General del Estado podrá otorgar una subvención para sufragar el alquiler de una vivienda similar a la siniestrada o los gastos de hospedaje, con un máximo de cobertura de $90 €$ diarios por persona si el alojamiento tiene lugar en un establecimiento hostelero o de $1.500 €$ si se trata del alquiler de una vivienda. En ambos casos, estos límites se modularán en atención a la composición de la unidad familiar ${ }^{95}$.

\subsection{Establecimientos mercantiles o industriales}

En el caso de establecimientos mercantiles o industriales, siempre que no sean de titularidad pública, el resarcimiento por los daños sufridos comprende, hasta el límite de $113.680 €$, el valor de las reparaciones necesarias para poner nuevamente en funcionamiento dichos establecimientos, incluyendo el mobiliario y el equipo siniestrado ${ }^{96}$. Asimismo, y con independencia del resarcimientos por daños previstos en los artículos anteriores, la Administración General del Estado podrá, en supuestos excepcionales y, en particular, cuando como consecuencia del acto terrorista, se produzca la interrupción de la actividad productiva de una empresa con el consiguiente riesgo de regulaciones de empleo, acordar la subsidiación de préstamos abono a la entidad de crédito de la diferencia existente entre los pagos de amortización de capital e intereses al tipo de interés fijado por la entidad prestamista y los que corresponderían al tipo de interés subsidiado, que será

se haya residido en ella un tiempo equivalente, al menos, a la mitad del transcurrido desde la fecha en que hubiera comenzado la ocupación».

91 Arts. 24.1 de la Ley 29/2011 y 24.1 del Real Decreto 671/2013.

92 Art. 24.1 del Real Decreto 671/2013.

93 Arts. 24.2 de la Ley 29/2011 y 25 del Real Decreto 671/2013.

94 Art. 25.2 del Real Decreto 671/2013.

95 Art. 25.1 del Real Decreto 671/2013.

96 Arts. 25.1 de la Ley 29/2011 y 26.1 del Real Decreto 671/2013. 
el del interés legal del dinero en el acto de formalización del préstamo menos tres puntos- destinados a la reanudación de dicha actividad ${ }^{97}$. También la Administración General del Estado podrá celebrar convenios con entidades de crédito al objeto de que éstas establezcan modalidades de créditos a bajo interés con dicha finalidad ${ }^{98}$.

\subsection{Sedes de partidos políticos, sindicatos y organizaciones sociales}

Tratándose de actos terroristas contra las sedes de partidos políticos, sindicatos y organizaciones sociales, el resarcimiento se cuantifica en el valor total de las reparaciones necesarias -incluyendo la reposición del mobiliario y equipo siniestrado- para que puedan reanudar su actividad. Entre los daños indemnizables se incluirán, a estos efectos, los producidos en las sedes o lugares de culto pertenecientes a confesiones religiosas inscritas ${ }^{99}$.

\subsection{Vehículos}

Finalmente, también serán resarcibles los daños causados tanto en vehículos particulares como en los destinados al transporte terrestre de personas o mercancías, siempre y cuando estos no sean de titularidad pública y tengan vigente la póliza del seguro obligatorio del vehículo en el momento del siniestro. El resarcimiento comprenderá los gastos necesarios para su reparación, sin que, en el reglamento, se establezca límite alguno en cuanto a la cuantía $^{100}$. En caso de destrucción del vehículo, o cuando la reparación resulte superior al valor venal, la indemnización será equivalente al importe de adquisición de un vehículo de similares características técnicas y condiciones de uso al siniestrado, hasta el límite de $30.500 €^{101}$.

2.2.1.3. Procedimiento para la concesión de la ayuda por daños personales y materiales

El procedimiento para el reconocimiento de las ayuda, que se ajustará a lo dispuesto en la Ley 39/2015, de 1 de octubre, del Procedimiento Administrativo Común de las Administraciones Públicas, se iniciará siempre a solicitud de la persona interesada, directamente o por medio de un representante acreditado por cualquier medio válido en derecho que deje constancia fidedigna, impulsándose posteriormente de oficio en todos sus trámites ${ }^{102}$. Ésta deberá

\footnotetext{
97 Arts. 25.2 y 3 de la Ley 29/2011 y 26.2 del Real Decreto 671/2013.

98 Arts. 25.4 de la Ley 29/2011 y 26.3 del Real Decreto 671/2013.

99 Arts. 26 de la Ley 29/2011 y 27 del Real Decreto 671/2013.

100 El art. 29 del Real Decreto 288/2003 limitaba esa cuantía a 21.035,42€.

101 Arts. 27 de la Ley 29/2011 y 28 del Real Decreto 671/2013.

102 Art. 48.1 del Real Decreto 671/2013.
} 
acompañarse de la documentación acreditativa de la condición de víctima de terrorismo ${ }^{103} \mathrm{o}$, en su caso, del grado de parentesco con la víctima.

El plazo para la presentación de las solicitudes prescribirá una vez transcurrido un año desde que tuvo lugar el acto terrorista causante del daño ${ }^{104}$. El inicio del cómputo del plazo difiere, no obstante, según el tipo de daño: a) en caso de daño corporal el inicio del cómputo de dicho plazo será desde la fecha de alta o consolidación de secuelas. No obstante, si como consecuencia directa de las lesiones, se produjese un agravamiento de secuelas o el fallecimiento del afectado, se abrirá de nuevo el plazo de un año para solicitar la diferencia cuantitativa que proceda; $b$ ) en los casos de daños psicológicos, el inicio del cómputo empezará a contar desde el momento en el que exista un diagnóstico acreditativo de la causalidad de la secuela.

El cómputo de este plazo se verá suspendido hasta la incorporación al expediente indemnizatorio de las evaluaciones médicas de las lesiones y las tasaciones periciales de los daños materiales, cuando resulten determinante para adoptar la resolución ${ }^{105}$.

La calificación de las lesiones consecuencia de los actos terroristas, a efectos de valorar el nexo causal, será llevada a cabo por un equipo de valoración de incapacidades, cuya composición se establezca reglamentariamente. El equipo que proceda a tal valoración será determinado por el Instituto Nacional de Seguridad Social, en el que, en todo caso, se integrará un representante de la Dirección General de Apoyo a las Víctimas del Terrorismo del Ministerio del Interior ${ }^{106}$. Por lo que respecta a las víctimas no residentes en el territorio nacional, estipula el art. 11.3 del Real Decreto 671/2013 que «el dictamen se emitirá a la vista de los informes periciales evacuados con motivo de las actuaciones penales seguidas y de los informes y pruebas complementarias que sea preciso recabar de la delegación consular más próxima al lugar de la residencia de la víctima». En el caso de los miembros de las FCCSE, esta calificación se efectuará por sus respectivos tribunales debiendo estar presente, en todo caso, un representante de la Dirección General de Apoyo a Víctimas del Terrorismo ${ }^{107}$. Finalmente, la calificación

${ }^{103}$ A efectos de acreditar su condición de afectado, esta solicitud deberá acompañarse de alguna de la siguiente documentación: a) la sentencia firme en que se reconozca el derecho a ser indemnizado en concepto de responsabilidad civil por los hechos y daños contemplados en el ámbito de aplicación de la Ley; b) en ausencia de sentencia, y cuando se hubiesen iniciado las correspondientes diligencias judiciales o incoado el proceso penal por el enjuiciamiento de los delitos de terrorismo, por cualquier medio de prueba admisible en derecho.

\footnotetext{
104 Arts. 28.1 de la Ley 29/2011 y 49.1 del Real Decreto 671/2013.

105 Art. 28.4 de la Ley 29/2011.

106 Art. 11.1 del Real Decreto 671/2013.

107 Art. 11.4 del Real Decreto 671/2013.
} 
de las lesiones permanentes no invalidantes podrá efectuarse, en su caso, por la Asesoría Médica adscrita a la Unidad Administrativa instructora de los resarcimientos $^{108}$.

La tasación pericial de los daños materiales se realizará por los servicios competentes del Consorcio de Compensación de Seguros. En dicha tasación habrá de valorar tanto los daños indemnizables por el consorcio, con arreglo a su propia normativa, como los resarcibles por la Administración, conforme a lo dispuesto en este reglamento. Se podrá prescindir de la peritación cuando la cuantía total de los daños, acreditada mediante la factura o presupuesto de reparación originales, no alcance $600 €$, si constara a la Administración el cumplimiento de los demás requisitos exigibles ${ }^{109}$.

Las sentencias judiciales que reconozcan a los perjudicados daños indemnizables por la comisión de un acto terrorista y que no hayan sido objeto de un reconocimiento administrativo anterior, reabrirán el plazo de solicitud por el plazo de un año desde la notificación al órgano instructor de la firmeza de la sentencia judicial.

$\mathrm{Su}$ instrucción corresponderá al órgano competente en materia de atención a víctimas dependiente del Ministerio del Interior, que actuará como ventanilla única de cualquier otro procedimiento que el interesado pueda deducir ante la Administración General del Estado ${ }^{110}$. Estará presidida por los principios de celeridad y trato favorable a la víctima, no requiriéndose la aportación documental, por parte del interesado, de hechos notorios o circunstancias cuya acreditación conste en los antecedentes o archivos de la Administración actuante ${ }^{111}$. El órgano competente para la resolución de las solicitudes será la Dirección General de Apoyo a las Víctimas de Terrorismo del Ministerio del Interior. El plazo máximo para la resolución del procedimiento será de 12 meses, a contar desde que la solicitud haya tenido entrada en registro del Ministerio del Interior ${ }^{12}$. Transcurrido dicho plazo sin que se haya dictado resolución expresa, la petición de la concesión de la ayuda se considerará estimada ${ }^{113}$. Dicha resolución pone fin a la vía administrativa, pudiendo ser recurrida potestativamente en reposición o impugnada ante el orden jurisdiccional contencioso-administrativo ${ }^{114}$.

\footnotetext{
108 Art. 11.5 del Real Decreto 671/2013.

109 Art. 29 del Real Decreto 671/2013.

110 Art. 51.1 del Real Decreto 671/2013.

111 Art. 51.2 del Real Decreto 671/2013.

112 Arts. 28.6 de la Ley 29/2011 y 53.2 del Real Decreto 671/2013.

113 Arts. 28.6 de la Ley 29/2011 y 53.3 del Real Decreto 671/2013.

114 Art. 28.5 de la Ley 29/2011.
} 


\subsubsection{Abono de la responsabilidad civil fijada en sentencia}

La previsión del abono, con carácter extraordinario, por parte del Estado, de las indemnizaciones impuestas en sentencia firme en concepto de responsabilidad civil ex delicto es heredera de la Ley 32/1999, de 8 de octubre, de Solidaridad con las víctimas del terrorismo ${ }^{115}$. El principio de solidaridad queda, en este caso, ciertamente mediatizado, siendo la connotación principal de su regulación, la asunción por el Estado de una posición de garante del pago de la indemnización debida, ante la insolvencia del responsable civil. Se articula, de este modo, un auténtico sistema indemnizatorio, pero sin que ello implique la asunción, por el Estado, de responsabilidad subsidiaria alguna ${ }^{116}$.

\subsubsection{1. Ámbito de cobertura}

La indemnización se extenderá, exclusivamente, a los daños físicos o psíquicos ${ }^{117}$ sufridos a consecuencia de actos terroristas acaecidos desde el 1 de enero de $1960^{118}$, que causen un fallecimiento, una gran invalidez, una incapacidad permanente total, una incapacidad permanente parcial, lesiones permanentes no invalidantes o un secuestro ${ }^{119}$.

\subsubsection{2. Ámbito subjetivo}

La indemnización se abonará a la persona que haya sufrido daños físicos o psíquicos como consecuencia de un acto terrorista. En caso de fallecimiento de la víctima, el derecho resarcitorio corresponderá, por orden de preferencia $^{120}$ : a) al cónyuge de la persona fallecida, si no estuviera separado legalmente, o la persona con la que hubiera venido conviviendo con ella de forma permanente con análoga relación de afectividad durante, al menos, los dos años anteriores al momento del fallecimiento, salvo que hubieran tenido descendencia en común, en cuyo caso bastará la mera convivencia; y los hijos de la persona fallecida; b) en ausencia de los anteriores, serán beneficiarios de dicha indemnización por orden sucesivo y excluyente, los padres, los nietos, los hermanos y los abuelos de la persona fallecida; c) ante la falta de

115 BOE núm. 242, de 9 de octubre de 1999. Omar Mir PuigPelat, «Indemnizaciones a las víctimas del terrorismo. Ley 32/1999, de 8 de octubre, de solidaridad con las víctimas del terrorismo y su Reglamento de desarrollo», Indret: Revista para el Análisis del Derecho (2000), 1-10.

116 Arts. 20.7 de la Ley 29/2011 y 17.1 del Real Decreto 671/2013.

117 Art. 20.2 de la Ley 29/2011.

118 El art. 2.2 de la Ley 32/1999 limitaba la indemnización a los daños físicos o psíquicos sufridos a consecuencia de actos terroristas acaecidos entre el 1 de enero de 1968 y la fecha de entrada en vigor de la ley -9 de octubre de 1999-.

119 Arts. 20.4 de la Ley 29/2011 y 16.1 del Real Decreto 671/2013.

120 Art. 20.3 de la Ley 29/2011. 
todos ellos, siempre y cuando dependieran económicamente de la persona fallecida, los hijos de la persona conviviente y los menores en acogimiento familiar permanente; d) finalmente, en defecto de todos los anteriores, serán beneficiarios sus herederos o a quien se designe como destinatarios en la resolución judicial adoptada.

No se contempla en la nueva regulación, la eventualidad de que, en el caso de que fallezca alguno de los beneficiarios, la parte de la indemnización que le hubiere correspondido sea distribuida, entre sus propios herederos, con arreglo a las disposiciones hereditarias aplicables a su sucesión ${ }^{121}$. Asimismo, tampoco se prevé el hecho de que, la víctima incapacitada fallezca con posterioridad, la indemnización que hubiere correspondido al causante sea distribuida entre sus herederos, conforme a las disposiciones que hayan regido su sucesión ${ }^{122}$.

\subsubsection{Cuantía indemnizatoria}

La cuantía máxima de la indemnización a abonar por el Estado, en concepto de responsabilidad civil, diferirá en atención a sí en la sentencia firme se fija o no una cantidad en este concepto.

En el primer supuesto, la cantidad a abonar será la efectivamente fijada en la sentencia ${ }^{123}$, no pudiendo superar, en ningún caso, según el tipo de contingencia, las siguientes cuantías ${ }^{124}$ : a) fallecimiento (500.000€); b) gran invalidez $(750.000 €) ; c)$ incapacidad permanente absoluta $(300.000 €)$; e) incapacidad permanente total $(200.000 €)$; f) incapacidad permanente parcial (125.000€); g) lesiones no invalidantes (100.000€); h) secuestro (125.000€).

Este es uno de los cambios más significativos del actual régimen con respecto a la previsión contenida en el art. 6 de la Ley 32/1999. En el anterior sistema, la cuantía a satisfacer en concepto de responsabilidad civil era la fijada en la sentencia judicial firme, salvo que esa cantidad fuese inferior a la indemnización mínima que, en todo caso, deberían percibir las víctimas ${ }^{125}$. El legislador ha optado, en la regulación vigente, por el establecimiento de las cantidades máximas a abonar, de forma extraordinaria, por el Estado, con la finalidad de garantizar «un trato más equitativo en orden a la compensación, evitando en todo caso respuestas desiguales ante supuestos similares» ${ }^{126}$.

Cuando la sentencia firme no reconociera ni permitiera reconocer una cantidad en concepto de responsabilidad civil, se abonarán, según el tipo de

121 Art. 15 del Real Decreto 1912/1999.

122 Art. 18.2 del Real Decreto 1912/1999.

123 Art. 16.2 del Real Decreto 671/2013.

124 Arts. 20.4 de la Ley 29/2011 y 16.3 del Real Decreto 671/2013.

125 Mir Puigpelat, «Indemnizaciones a las víctimas del terrorismo», 6.

126 Apartado I de la Exposición de Motivos de la Ley 29/2011. 
contingencia, las cuantías señaladas en el régimen ordinario de ayudas a las víctimas del terrorismo ${ }^{127}$.

En aquellos supuestos en los que las víctimas o sus beneficiarios hubieran recibido las ayudas por daños personales que se prevén en el art. 18, este abono extraordinario se limitará a la diferencia existente entre las ayudas ya percibidas y la indemnización fijada en sentencia, eso sí, con los límites ya señalados ${ }^{128}$. Se modifica de forma notable, por tanto, el régimen de compatibilidades previsto en la anterior regulación, del que se infería la aceptabilidad de su concurrencia con la compensación ordinaria ${ }^{129}$.

\subsubsection{Acción de subrogación}

El Estado se subrogará, hasta el límite de la indemnización satisfecha, en las acciones que las víctimas o sus beneficiarios puedan ejercer contra el obligado civilmente por el total del importe de la indemnización por él satisfecha ${ }^{130}$. A estos efectos deberán, con carácter previo a la percepción de la indemnización, transmitir al Estado las acciones civiles correspondientes ${ }^{131}$.

No obstante, en aquellos casos en los que la cuantía de la indemnización fijada en la sentencia sea superior al importe satisfecho por el Estado, el beneficiario conservará la acción civil para reclamar la diferencia a los responsables de la acción delictiva causante de los daños ${ }^{132}$.

\subsubsection{Plazo de presentación de la solicitud}

El plazo para solicitar, de acuerdo al procedimiento ya visto, el abono con carácter extraordinario de la responsabilidad civil fijada en sentencia firme será de un año desde la notificación al interesado de la sentencia o, en su caso, de la resolución judicial que fije la cuantía indemnizatoria ${ }^{133}$.

\subsubsection{Ayudas extraordinarias}

La Ley 29/2011 contempla también la posibilidad de otorgar ayudas extraordinarias para paliar situaciones de necesidad personal o familiar de las

127 Art. 16.2.b) del Real Decreto 671/2013.

128 Art. 17.2 del Real Decreto 671/2013.

129 ROIG TORRES, La reparación ..., 330; Víctor FAIRÉN GUILLÉN, «Acción, proceso y ayuda a las víctimas del delito», La Ley: Revista jurídica española de doctrina, jurisprudencia y bibliografía, n. 3 (1991), 886.

130 Arts. 21.1 de la Ley 29/2011 y 18.1 del Real Decreto 671/2013.

131 Arts. 21.1 de la Ley 29/2011 y 18.3 del Real Decreto 671/2013.

132 Arts. 21.2 de la Ley 29/2011 y 18.2 del Real Decreto 671/2013.

133 Art. 49.2 del Real Decreto 671/2013. 
víctimas, no cubiertas o cubiertas insuficientemente por las ordinarias ${ }^{134}$. Así, en los supuestos de daños personales, las ayudas podrán cubrir necesidades sociales, sanitarias, psicológicas o educativas, previa evaluación efectuada por los órganos competentes del Ministerio del Interior ${ }^{135}$. Por lo que respecta a los daños materiales, las ayudas podrán destinarse a la adaptación o cambio de vivienda cuando las secuelas del atentado terrorista así lo exijan, así como a la satisfacción de otras necesidades personales o familiares derivadas de la acción terrorista ${ }^{136}$.

Estas ayudas son compatibles, en todo caso, con las ayudas ordinarias previstas por la ley ${ }^{137}$. Su solicitud podrá ser cursada por las víctimas, sus familiares o las personas con quienes convivan, o promovidas de oficio -en caso de urgencia- por la Subdirección general de Atención al ciudadano y de Asistencia a las víctimas del Terrorismo que será la encargada de elevar al Ministerio del Interior, en su caso, la propuesta de concesión ${ }^{138}$.

\subsubsection{Asistencia sanitaria}

Las personas que hayan sufrido daños físicos y/o psíquicos como consecuencia de un acto terrorista así como, en caso de fallecimiento, sus beneficiarios, podrán recibir ayudas específicas destinadas a financiar tratamientos médicos, prótesis e intervenciones quirúrgicas ${ }^{139}$. Para ello deberán acreditar su necesidad y que la concreta prestación requerida no se halla cubierta, bien por el sistema público sanitario o un seguro privado, bien por el régimen ordinario de ayudas a las víctimas de actos terroristas ${ }^{140}$. A efectos de corroborar estos extremos, la solicitud se acompañará de un informe médico acreditativo de su necesidad y una certificación de la entidad aseguradora de la víctima de que la ayuda no entra dentro de la cobertura de sus prestaciones. El órgano instructor podrá recabar, por sí mismo, la certificación anterior,

134 Art. 36 de la Ley 29/2011. Otros ejemplos de esta normativa extraordinaria en materia de ayuda a las víctimas del terrorismo sería el Real Decreto-Ley 13/1997, de 1 de agosto, por el que se autoriza la celebración de un sorteo de la Lotería Nacional a favor de las víctimas del terrorismo, el cual fue celebrado el 18 de octubre de 1997. Los criterios de distribución de las ayudas, así como el procedimiento aplicable fueron regulados por el Real Decreto 73/1998, de 23 de enero. Esta iniciativa tenía carácter único y excepcional aunque los resultados obtenidos dejan «abierta la posibilidad de que en futuro pueda insistirse en fórmulas de signo semejante». LANDRove DíAz, La moderna ..., 156.

135 Art. 42.2 del Real Decreto 671/2013.

136 Art. 42.3 del Real Decreto 671/2013.

137 Arts. 36 de la Ley 29/2011 y 42.5 del Real Decreto 671/2013.

138 Art. 42.5 del Real Decreto 671/2013.

139 Arts. 32.1 de la Ley 29/2011 y 32.1 del Real Decreto 671/2013.

140 Arts. 32.1 y 3 de la Ley 29/2011 y 32.1 del Real Decreto 671/2013. 
previo consentimiento del interesado, cuando el sistema de aseguramiento o previsión sea público ${ }^{141}$.

Asimismo, también será objeto de financiación el coste de la atención psicológica que, previa prescripción facultativa, requieran las víctimas, los amenazados $^{142}$, sus familiares o personas con quienes convivan. El límite de la ayuda será, en este caso, de $3.600 €$ por tratamiento individualizado ${ }^{143}$. A tal efecto, la Administración General del Estado podrá establecer los oportunos conciertos con otras Administraciones Públicas o con entidades privadas especializadas en dicha asistencia ${ }^{144}$.

\subsubsection{Adaptación de viviendas}

Las Administraciones Públicas acordarán las medidas necesarias para que las víctimas de terrorismo que, como consecuencia del acto terrorista sufrido, deban abandonar su domicilio habitual, tengan una consideración preferente en la adjudicación de vivienda de protección pública, bien para su compra bien para su arrendamiento ${ }^{145}$.

De forma complementaria al resarcimiento de los daños en la vivienda, la ley prevé el otorgamiento de ayudas para la adaptación de las viviendas de aquellas víctimas que, en atención a las secuelas derivadas del acto terrorista sufrido, así lo requieran ${ }^{146}$.

\subsubsection{Educación}

Las ayudas al estudio están destinadas a aquellos estudiantes que, como consecuencia de un acto terrorista, sufran, ellos mismos o su viudo o viuda, pareja de hecho o hijos del fallecido, sus padres, hermanos, tutores o guardadores, daños personales que sean de especial trascendencia o que los inhabilite para el ejercicio de su profesión habitual ${ }^{147}$.

Estas podrán concederse para iniciar o proseguir enseñanzas, en los distintos niveles, en las siguientes cuantías ${ }^{148}$ : primer infantil (1.000€), segundo ciclo de educación infantil y educación primaria $(400 €)$, bachillerato (1.000€),

141 Art. 32.2 del Real Decreto 671/2013.

142 Tendrán la consideración de amenazados, de acuerdo con el art. 5 de la Ley 29/2011, «las personas que acrediten, en los términos del art. 3 bis de la Ley, sufrir situaciones de amenazas o coacciones directas y reiteradas, procedentes de organizaciones terroristas, serán objeto de especial atención, en el marco de sus competencias por parte de las Administraciones Públicas»».

143 Art. 33.1 del Real Decreto 671/2013.

144 Art. 33.2 del Real Decreto 671/2013.

145 Arts. 37.1 y 2 de la Ley 29/2011 y 40 del Real Decreto 671/2013.

146 Arts. 37.3 de la Ley 29/2011 y 41 del Real Decreto 671/2013.

147 Arts. 39.1 de la Ley 29/2011 y 35 del Real Decreto 671/2013.

148 Art. 36.1 del Real Decreto 671/2013. 
formación profesional de grado medio y superior (1.500€), grado o equivalente $(1.500 €)$, máster $(1.500 €)$, otros estudios $(750 €)$ y enseñanzas de idiomas en centros oficiales $(300 €)$. Estas cantidades se incrementarán en un $20 \%$, si el centro de estudios se ubica, al menos, a $50 \mathrm{~km}$ de la localidad en la que se encuentra su domicilio familiar, y en un $40 \%$, si la asistencia al citado centro implica cambio de residencia respecto del domicilio familiar ${ }^{149}$.

Las ayudas pueden otorgarse, tanto para el pago de la matrícula de estudios, como del material escolar, el transporte, la residencia, así como en concepto de atención compensatoria a la familia por la dedicación al estudio de alguno de sus miembros. Los tipos de estudios cubiertos por las ayudas, las clases y cuantías de las mismas, los requisitos económicos y académicos, y las obligaciones de sus beneficiarios, su concesión y renovación se ajustarán al sistema establecido en el Real Decreto 1721/2007, de 21 de diciembre, por el que se establece el régimen de becas y ayudas al estudio ${ }^{150}$.

No obstante, a efectos de calcular los rendimientos académicos mínimos exigidos a los beneficiarios de las ayudas al estudio, se corregirán las calificaciones medias señaladas con la multiplicación por un coeficiente reductor del 0,60 a aquellos alumnos con necesidades específicas de apoyo educativo que requieran de una adaptación curricular o de un aumento de tiempos para realizar los estudios en los supuestos de incapacidad física o psíquica ${ }^{151}$. Asimismo, de forma motivada, se podrá eximir del cumplimiento de los requisitos académicos mínimos al solicitante de la ayuda, atendiendo a la fecha de comisión del atentado terrorista o a su repercusión en el propio solicitante y/o en su ámbito familiar ${ }^{152}$.

El plazo para la presentación de la solicitud -a la que se le deberá adjuntar, además de la documentación que al efecto establezca el Ministerio de Educación, Cultura y Deporte, una certificación del Ministerio del Interior acreditativa de la cualidad de víctima o beneficiario ${ }^{153}$ - será de tres meses desde la formalización de la matrícula del curso para el que se solicita la ayuda ${ }^{154}$.

Las ayudas al estudio percibidas por la condición de víctima de terrorismo serán incompatibles con las percibidas por los mismos conceptos de otras de otras Administraciones Públicas o de instituciones privadas ${ }^{155}$.

\footnotetext{
149 Art. 36.2 del Real Decreto 671/2013.

150 BOE núm. 15, de 17 de enero de 2008. Art. 37.2 del Real Decreto 671/2013.

151 Art. 37.2 del Real Decreto 671/2013.

152 Art. 37.3 del Real Decreto 671/2013.

153 Art. 48.1 del Real Decreto 671/2013.

154 Art. 49.3 del Real Decreto 671/2013.

155 Art. 38.1 del Real Decreto 671/2013.
} 
Junto a esta ayuda, se procederá a eximir del pago de las tasas académicas en los centros oficiales de estudios a las víctimas de actos terroristas, así como a los hijos ${ }^{156}$.

\section{CONCLUSIONES}

A la luz del análisis efectuado podemos concluir que España cuenta con un avanzado sistema de protección de las víctimas del terrorismo. La Ley 29/2011 ha procedido a unificar las diversas prestaciones que, hasta ese momento, eran reguladas de manera diferenciada en diversas normas. Se articula, de este modo, un nuevo régimen compensatorio en que se distinguen tres tipos de ayudas -ordinarias, extraordinarias y el abono por el Estado de la responsabilidad civil fijada en sentencia- que buscan garantizar la asistencia integral de las víctimas en sus distintas necesidades.

Esta ley ha venido a incrementar el importe de las compensaciones económicas y a ampliar sus ámbitos objetivo y subjetivo de aplicación, abarcando, por primera vez, a las víctimas de actos terroristas cometidos fuera del territorio nacional que tengan nacionalidad española. El principio de territorialidad que con carácter general rige en las leyes sobre compensación estatal se ve aquí sustituido por el principio de ciudadanía.

Otro de los cambios más significativos del actual régimen es el establecimiento de un límite máximo de las cantidades a abonar, en concepto de la responsabilidad civil fijada en sentencia, por el Estado, evitándose, de esta forma, respuestas desiguales ante supuestos similares. Es destacable, igualmente, el carácter retroactivo que presentan sus disposiciones, abarcando todos los actos terroristas acaecidos con posterioridad al 1 de enero de 1960.

En el capítulo de las críticas debe anotarse, no obstante, la laxitud con que el Ministerio del Interior y los órganos judiciales excluyen de su ámbito de aplicación, sobre la base de la excepción potestativa contemplada en el art. 8.2 del Convenio Europeo sobre indemnizaciones a víctimas de delitos violentos de 1983, a las víctimas de grupos parapoliciales contraterroristas que hubieran participado en la delincuencia organizada o perteneciesen a un grupo dedicado a la comisión de delitos violentos. La correcta observancia del principio de legalidad y del derecho a tutela judicial efectiva exige, en todo caso, para la adopción de esta decisión, la concurrencia de dos requisitos: la previa condena por sentencia judicial firme por la comisión de alguno de los delitos comprendidos en los arts. 571 y ss. CP y la adquisición de la condición de víctima de terrorismo con posterioridad a la entrada en vigor el art. 3 bis de la Ley 29/2011-1 de enero de 2013-.

${ }^{156}$ Arts. 38 de la Ley 29/2011 y 39 del Real Decreto 671/2013. 


\section{BIBLIOGRAFÍA}

Castañón Álvarez, María José, Victimas del terrorismo: Protección y tutela. Granada: Comares, 2013.

FAIRÉN GUILLÉN, Víctor, «Acción, proceso y ayuda a las víctimas del delito», La Ley: Revista jurídica española de doctrina, jurisprudencia y bibliografía, n. ${ }^{\circ} 3$ (1991), 863-881.

Ferreiro BaAmonde, Xulio, La víctima en el proceso penal. Madrid: La Ley, 2005. GARZÓN VALDÉS, Ernesto, «El terrorismo político no institucional: propuesta de definición», Claves de Razón Práctica, n. ${ }^{\mathrm{o}} 118$ (2001): 4-11.

Herrera Moreno, Myriam, La hora de la víctima. Compendio de Victimología. Madrid: Edersa, 1996.

LANDROve DíAz, Gerardo, La moderna victimología. Valencia: Tirant lo Blanch, 1998.

MARTínez-CARDos Ruiz, José Leandro, El resarcimiento estatal de daños causados por bandas y grupos armados. Tesis doctoral. Universidad Complutense de Madrid, 1996.

Mir PuigPelat, Omar, «Indemnizaciones a las víctimas del terrorismo. Ley 32/1999, de 8 de octubre, de solidaridad con las víctimas del terrorismo y su Reglamento de desarrollo», Indret: Revista para el Análisis del Derecho (2000), 1-10.

MuÑAgorri Laguía, Ignacio y PÉREz Machío, Ana Isabel, «Aproximación al sentido y alcance del art. 8.2 del Convenio Europeo sobre indemnizaciones a víctimas de delitos violentos de 1983. Tensiones con el principio de legalidad», Revisa Vasca de Administración Pública, núm. especial 99-100 (2014), 2107-2128.

Roca Agapito, Luis, «Análisis del nuevo régimen jurídico-económico de las víctimas del terrorismo», Diario La Ley, n. ${ }^{\circ} 7776$ (2012), 1-17.

RoIg TORRES, Margarita, La reparación del daño causado por el delito: aspectos civiles y penales. Valencia: Tirant lo Blanch, 2000.

Sempere Navarro, Antonio Vicente y Kahale Carrillo, Djamil Tony (coords.), Reconocimiento y protección integral de las víctimas del terrorismo. Madrid: Eolas, 2014.

Serrano Galvis, Samuel, Reparación de los daños causados por el terrorismo. Tesis Doctoral. Universidad de Salamanca, 2009.

SOlÉ RIERA, Jaume, La tutela de la víctima en el proceso penal. Barcelona: J.M. ${ }^{a}$ Bosch Editor, 1997.

SuBIJANA ZunZUNEGUI, Ignacio José, El principio de protección de las víctimas en el orden jurídico pena. Del olvido al reconocimiento. Granada: Comares, 2006.

TAMARIT Sumalla, Josep María, «Paradojas y patologías en la construcción social, política y jurídica de la victimidad», Indret: Revista para el Análisis del Derecho (2013): 1-31.

La reparación a la víctima en el derecho penal. Barcelona: Fundación Jaume Callís, 1994.

TITLE: The compensatory aids to the victims of terrorism: analysis of the Act 29/2011 and its development regulation 
RESUMEN: En el presente trabajo se analiza el régimen estatal de ayudas a las víctimas de terrorismo. Éste se encuentra regulado, actualmente, por la Ley 29/2011, de 22 de septiembre, de reconocimiento y protección integral a las víctimas del terrorismo y por su reglamento de desarrollo aprobado por el Real Decreto 671/2013, de 6 de septiembre. En el marco de este régimen distinguimos tres tipos de ayudas-ordinarias, extraordinarias y el abono por el Estado de la responsabilidad civil fijada en sentencia-que responden a distintas necesidades

PALABRAS CLAVE: víctimas, terrorismo, reparación, Estado.

ABSTRACT: The aim of this article is to analyze the national regime of the aids to the victims of terrorism. Currently, this is regulated by the Act 29/2011, of 22nd September, on the recognition and comprehensive protection of victims of terrorism and by its development regulation approved by the Royal Decree 671/2013, of 6th September. In the frame of this Act we can distinguish three types of compensations: ordinary compensations, extraordinary compensations and the payment by the State of the sum imposed as civil liability by the Courts.

KEY WORDS: victims, terrorism, compensation, State. 